\title{
Web System to Support Teaching of Molecular Biology and Bioinformatics
}

\author{
http://dx.doi.org/10.3991/ijes.v2i3.3819 \\ P.H. Rezende and M.E. Franco \\ IFSULDEMINAS - Campus Machado/ Computing Department, Machado, Brazil
}

\begin{abstract}
The process of teaching learning molecular biology and bioinformatics in IFSULDEMINAS - Campus Machado has limitations regarding the tools used. Through non- directive interviews with students and teachers who study the discipline of molecular biology there is the difficulty in learning the content by the students and also the challenge for teachers to make the subject that is more playful rather abstract and better understanding by the student . Faced with the problem a literature search on the areas of education and biology education was undertaken to try to consider these reflections in the solution to be developed. From the survey, a web content system was developed for molecular biology and bioinformatics routines transcribing gene sequences and queries to the database using the NCBI BLAST tool, through the .NET Bio library. The system has access controls and the contents are divided into modules. The creation of a web system to support the teaching of molecular biology and genetics seeks to contribute to the learning of the contents of these disciplines showing up as a complement to traditional expository approach.
\end{abstract}

Index Terms-Web learning environment, Teaching Biology, Bioinformatics.

\section{INTRODUCTION}

The use of computer systems has become an increasingly common practice in the school environment, while still not being a homogeneous reality among educational institutions. One of the earliest records of computer use in education, date of the $50 \mathrm{~s}$, where at the time a computer was used to solve problems related to a post-graduation, and in 1958 as "thinking machine" in do IBM Watson research center and the University of Illinois. In Brazil idea of computer use in the teaching-learning appeared around 1971 [1].

In this sense, many expectations were created keeping in view of changes in the educational process with the use of these tools. But what we see is not always the school reality in agreement to the technological reality in which we operate and when this premise is true remains to examine whether this use suggests changes in pedagogical approach or just solidifies the traditional approach to teaching based on practical that it is basically a transmission of knowledge.

Even with the advances in science technology biology teaching is still based almost exclusively on the methodology of expositive classes and restricted participation of students. The use of others teaching modalities such as movies, computer programs, extracurricular activities are, in most cases, due to the efforts of some teachers, but not a reality commonly found in classrooms [2]. Thus, we must consider the limitations in the teaching learning process of molecular genetics and bioinformatics in biology High-School Technical Courses and College of the IFSULDEMINAS-Campus Machado regarding the tools to support teaching courses of these contents. In this view, we propose the creation of the web system to support the teaching and learning of molecular biology and bioinformatics process.

\section{A. Computing applied to biology teaching}

The understanding of "computers in education" consists in the fact that one teacher of any discipline from an any course (High-School or College) discovers the educational potential of computer and this way, he can use his knowledge teaching traditional methods and activities using the computer tools. This is possible in all areas of teaching, but some fields of science that are more closely connected computing this approach becomes even easier [1].

In this context, we cannot fail to mention the field of molecular biology. With the use of information and new technologies, significant advances through scientific research findings yielded in that revolutionized science. We can cite as an example the study of nucleotides. For their study it is necessary to process and store large amount of information. However, it was only possible with the use of the computer, creating biological database and building tools for research and analysis [3].

Despite the multidisciplinary exist between areas of computer science and molecular biology, these tools are not always used in the classroom. Among the possible reasons, we can point out the unfamiliarity, the complex interface of these tools and the fact that all material in most they are written in English.

Because of the importance of the correct use of computers and other technological tools in teachinglearning process and existing tools for research and manipulation of genomic data has proposed the creation of a web system to support the educational process in the discipline of molecular biology and bioinformatics. Thus we intend to bring these restricted to scientific technologies within the school environment and try to contribute to a pedagogical approach a little less transmissive [3].

\section{Material AND Methods}

For the development of web system were followed a few steps that begins with exploratory research, literature research and application development.

The methodology of this study is based on action research, which is defined as "a type of empirical research 
base that is designed and carried out in close association with an action or to solve any problem and collective in which researchers and participants representative of the situation or problem are involved in a cooperative and participatory manner "[4]. For being an action research, unlike the classic research, which begins with a literature that one emphasizes the direct contact with the field will be studied and where the solution is applied. In this sense, in view of a better understanding of the practical teaching of the content of molecular biology and genetics in the discipline of biology, non-directive interviews with students and teachers were held.

In interviews with teachers, they reported about the difficulty in teaching the content because these are very abstract and result in too much theory. In view of these teachers, this may contribute to the difficulty of students' attention. When asked about the possibility of a web system that could assist the teaching-learning process of these contents, they showed great enthusiasm.

Because the work involves the areas of education, technology and teaching in biology, it was also made a literature search with the reading of books and articles of the principal authors of the respective areas in order to consider the reflections given in the construction of the system and we can highlight authors like Veiga [5], Lepienski \& Pine [6] and Krasilchilk [7].

In the development stage of the system, first a survey was conducted on the technologies that could be used for development work. After some research we selected the framework .NET that is an integration with biological database and implementations of key algorithms in bioinformatics through the project .NET BIO [8].

This system was based on development methodologies RAD systems (Rapid Application Development). The same was developed in .NET framework in C \# language and using database MySQL [9].

\section{RESULTS AND DISCUSSION}

From the interviews with the teachers teaching biology, they reported difficulty in teaching the content of molecular biology because these are very abstract and result in too much theory. This thought communes with Valente [1] asserting that when knowledge is transmitted only, it is difficult to obtain meaningful learning. In the opinion of these teachers, excess lectures may contribute to the difficulty of students' attention. In this perspective, it is worth mentioning the work of Krasilchik [7] shows that the overuse of lectures in teaching biology.

\section{A. Using the Web Tool in the Teaching of Molecular Biology.}

In order to get an insight into the pedagogical use of the tool we conducted interviews with specific teacher of this area. The system was presented and explained how to give your operation. The teacher commented that one of the major shortcomings in teacher formation concerns the understanding of basic concepts of molecular biology. From this information, we asked to the teacher what would be the possible causes responsible for this problem. In his opinion, memorizing content instead of real learning is the major cause of this problem.

It is important to emphasize that the opinion of the interviewee follows the same thought defended by Lepienski \& Pine [2] when he warns about excess lectures and lack of understanding of the content. The interviewee was also asked if using the system developed in this work this problem could be alleviated. According to his thinking, a web system like the one developed in this project can indeed contribute significantly to the understanding of content related to molecular biology. Further stated that in Module 2 of the application, when the student query sequence and performs the transcription / translation, the teacher can guide the student to make changes in the sequence, compare and check the result, for example, if it has mutated. Herein, the construction of knowledge supported by Valente [1].

\section{B. The Developed System}

The system has a login routine that allows the user selection into categories (teacher or student). Through these categories differentiated privileges, such as reporting, only users are defined grade teacher.

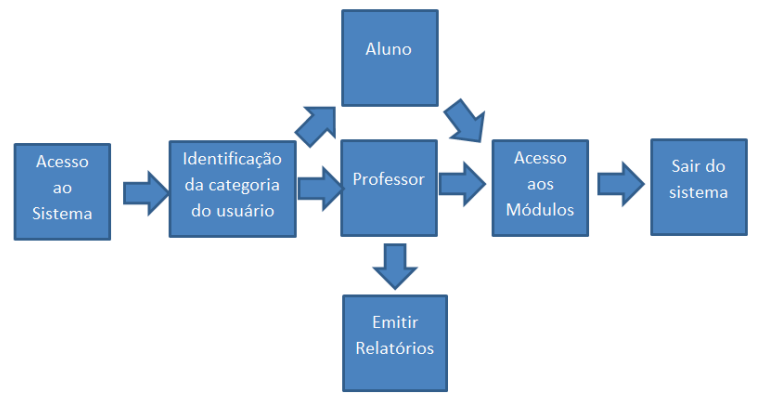

Figure 1. Basic flow system

The contents of the application is divided in three modules. There is a routine that checks and stores in the bank which modules the user accessed and how long he has remained connected to the module and the application as a whole. First, the user can access to Module 1 and he gets a minimum amount of time on the page, after he can go to Module 2, otherwise he will be informed that not accessed and / or did not remain long enough in the previous module and therefore is being redirected.

In Module 1 of the application, the user has access to content related to the study of nucleotides as its structure, properties, the process of translation and transcription. The content is based on textual and multimedia material.

In Module 2 application allows the user to insert a DNA sequence and perform its transcription into RNA and translation into amino acids. For this, it was created .NET Bio library, which is a set of tools for the analysis and manipulation of genomic information was used .NET Bio library is constructed based on .NET framework 4.0 and have opened under Apache License 2.0 code. The .NET Bio provides several useful components for biological analysis as reading and writing parsers for common bioinformatics formats, support sequences of DNA, RNA and Proteins, web connector for integration with web services.

The user can enter the sequence shown directly in the field or else it loads a file. By clicking the button that performs the transcription / translation of the DNA sequence will be presented to the user, and can identify the same proteins using the codon table. 


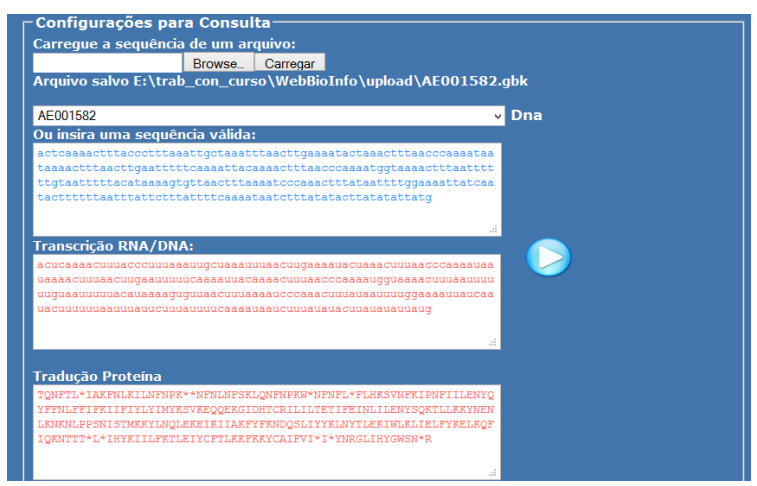

Figure 2. Transcription of an RNA sequence

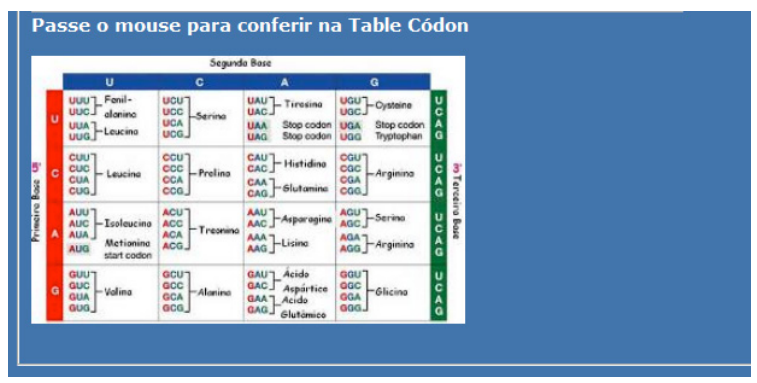

Figure 3. Códon Table

The Module 3 have a BLAST where the integration will be possible for the student through a simple interface to query gene sequences in the NCBI database. The NBCI (National Center for Biotechnology Information U.S.) is the central database of genomic information [10]. There are other important databases such as EMBL and DDBJ Europe from Japan, but all exchange data at an interval of 24 hours with the NCBI. The NCBI has several databases, including the most important is that stores all GenBank DNA sequences available, either a full or genome contigs - To perform the access and query these databases as a connection to the NCBI Blast tool, where you can run queries on any of these banks was implemented. In the NCBI site there is a menu to access the tool and search sequences in the database, but all the content is in English and the interface is quite complex for ordinary users. Therefore, this system module, through the use of the web framework .NET Bio integration with Blast [11] tool was performed.

The user can perform your search in the database of nucleotides and proteins. After defining the type of sequence he wants to search, he must enter a valid sequence password and click the button that performs the search.

The information about the user access to the system and specifically in each module are registered in the bank. The recording of such information enables the generation of reports. The application has a page for the teacher can monitor the student's access to information in the system. Therefore, only the user classified as Teacher can check the access time of each user, the last week, and since the first access history logs of the same on the last 10 days.

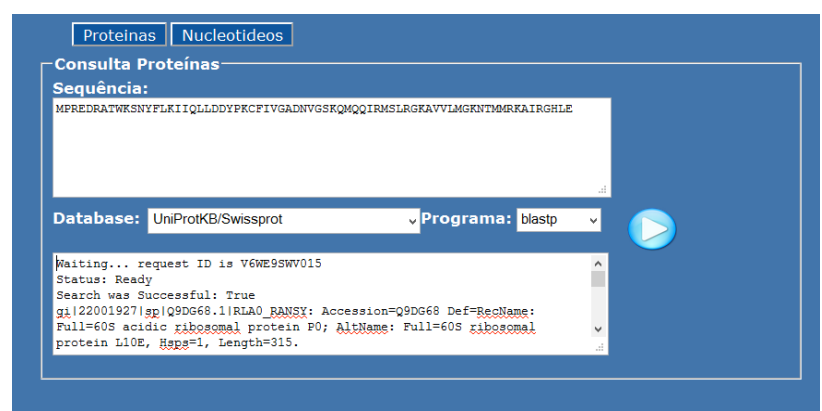

Figure 4. Query sequence in a protein-based

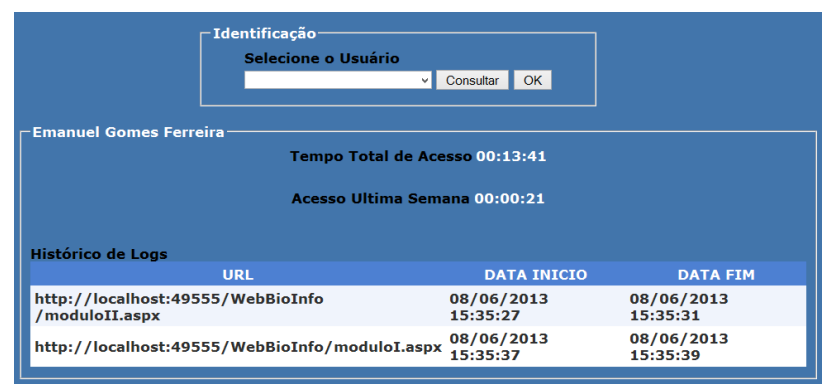

Figure 5. Issue report on user access

\section{CONCLUSIONS}

By observing the scenario of information technology in modern society, it is evident his great influence and contribution to performing various tasks, including educational and scientific context. Because of this progress, some areas have excelled and achieved accomplishments ever achieved without the contribution of computing, and we can highlight the area of bioinformatics.

In the specific case of the teaching of biology in schools, it can be seen - through reflections and analysis from experts in the area that are not always differentiated use of resources for teaching discipline, despite consider fertile ground for creativity and innovation. This was also observed through non-directive interviews with professors of molecular biology of IFSULDEMINAS-Campus Machado and their students. According to them, there was no usable tools that could make the teaching of molecular biology and genetics, less abstract and more attractive to students, and they found it hard learning the content.

The creation of a web system to support the teaching of molecular biology and genetics sought to contribute to the learning of the contents of these disciplines. Obviously the use of the tool must be pre planned and set in a didactic and pedagogical context.

\section{ACKNOWLEDGMENT}

Our thanks to Pro Rector for Research, Innovation and Graduate Instituto Federal de Educação, Ciência e Tecnologia do Sul de Minas Gerais for the support and encouragement they have provided the scientific productions, including this one.

Prof. Me Matheus Eloy Franco, for guidance and significant contribution that dispensed this work. 
PAPER

Web System to Support Teaching of Molecular Biology and Bioinformatics

\section{REFERENCES}

[1] VALENTE, José Armando. O Computador na Sociedade do Conhecimento. Campinas: Unicamp, 1999. 156 p.

[2] Lepienski, Luis Marcos \& Pinho, Kátia E. Prus. Recursos didáticos no ensino de biologia e ciências. Disponível em $<$ http://www.diadiaeducacao.pr.gov.br/portals/pde/arquivos/4002.pdf $>$. Acesso em 19 abr. 2013.

[3] OUZOUNIS, Christos A.; VALENCIA , Alfonso. Early bioinformatics: the birth of a discipline a personal view. Bioinformatics 19(17). Oxford University Press: 2003

[4] GIL, Antônio Carlos. Como elaborar projetos de pesquisa. São Paulo: Atlas, 2002, 4 a edição.

[5] VEIGA,I. Didática: Uma retrospectiva histórica. En:I.Veiga (Ed.), Repensando a Didática(pp. 82-95). Campinas: Papirus.

[6] Lepienski, Luis Marcos \& Pinho, Kátia E. Prus. Recursos didáticos no ensino de biologia e ciências. Disponível em $<$ http://www.diadiaeducacao.pr.gov.br/portals/pde/arquivos/4002.pdf>. Acesso em 19 abr. 2013.

[7] KRASILCHIK, Myriam. Prática de ensino de biologia.São Paulo, Editora da Universidade de São Paulo, 2011.

[8] .NETBIO Framework Overview. Disponível em: $<$ http://bio.codeplex.com/releases/view/81464.> Acesso $06 \mathrm{em}$ Abr. 2012.

[9] Mysql 5.6 Reference Manual. Disponível em< http://dev.mysql.com/doc/refman/5.6/en/>. Acesso $10 \mathrm{em} \mathrm{Mai.}$ 2012.
[10] About NCBI. Disponível em <http://www.ncbi.nlm.nih.gov/ About/index.html $>$. Acesso em 10 mar. 2012.

[11] SANTOS, Fabrício \& ORTEGA, José Miguel. Bioinformática aplicada a genômica. Disponível em $<$ http://www.icb.ufmg.br/lbem/aulas/grad/tge/bioinfo/bioinfogeno mica.pdf>. Acesso em 15 out. 2012.

\section{AUTHORS}

P. H. Rezende is with the Instituto Federal de Educação, Ciência e Tecnologia do Sul de Minas GeraisCampus Machado (IFSULDEMINAS), Machado -Minas Gerais- Brasil CEP: 37750-000 (e-mail: paulo.rezende@ifsuldeminas.edu.br).

M. E. Franco is with the Instituto Federal de Educação, Ciência e Tecnologia do Sul de Minas Gerais- Campus Machado (IFSULDEMINAS), Machado -Minas GeraisBrasil CEP: 37750-000 (e-mail: matheus.franco@ifsuldeminas.edu.br).

This article is an extended and modified version of a paper presented at the ICBL2013 International Conference on Interactive Computer aided Blended Learning, held 6 - 8 November 2013, in Florianópolis, Brasil. Submitted 29 April 2014. Published as resubmitted by the authors 07 August 2014. 